\title{
剥離操作における腹腔鏡手術用鉗子先端の作用力計測
}

\author{
吉田 健志 ${ }^{1) *}$, 木下 秀文 ${ }^{1)}$, 黒田 嘉宏 ${ }^{2)}$, 大城 理 $^{2)}$, 松田 公志 ${ }^{1)}$ \\ 1) 関西医科大学大学院医学研究科医科学専攻生体応答系泌尿器科学 \\ 2) 大阪大学大学院基礎工学研究科
}

\section{Force Measurement of Laparoscopic Instrument Tip during Dissection Procedure}

\author{
Kenji Yoshida $^{1) *}$, Hidefumi Kinoshita ${ }^{1)}$, Yoshihiro Kuroda ${ }^{2)}$ \\ Osamu Oshiro ${ }^{2)}$, Tadashi Matsuda ${ }^{1)}$ \\ ${ }^{1)}$ Department of Urology, Graduate School of Medicine, Kansai Medical University \\ ${ }^{2)}$ Graduate School of Engineering Science, Osaka University
}

Recieved 22 March, 2014 / Accepted 14 May, 2014

\begin{abstract}
:
When comparing a single stroke dissection maneuver among surgeons with differing experience levels, there are major differences in the force applied to the instrument tip. However, it is difficult for expert surgeons to explain to novice surgeons in training the appropriate force during dissection procedure. We developed the force measurement system which can quantify the force pattern during single-stroke laparoscopic dissection maneuvers to reveal the factors related to expertise. Expert surgeons apply the most efficient vertical forces to make an initial dissection point and then change to the horizontal direction to separate surrounding tissues from the target organ. Measuring instrument tip force could help in understanding and improving the safety margin in laparoscopic surgical dissection.
\end{abstract}

Key words: laparoscopic surgery, Skill analysis, Force measurement

要旨：

手術操作のらち臓器から臓器を剥がす剥離操作を行ら際, 腹腔鏡手術においては鈿子先端に加わる作用力を 推測することが容易でないことから, 剥離技能を言葉で初心者に伝達することが困難である. 今回我々は, 腹 腔鏡手術に抢ける剥離操作の際の作用力（垂直力，水平力）を計測することが可能なシステムを作成し，レべ ルの異なる術者が剥離操作を行ら際, 操作中に鉗子先端にどのような力を加え剥離操作を行らのかといら技能 分析を行った. 今回の検討から, 熟練者は始めに弱い水平力とともに垂直力を加えた後, 垂直力を減らしなが ら水平力を増加させて扣り，鉗子の先端が剥離開始点より奥に進まないように効率よく力を加えていることが 推察された。一方で初心者は, 剥離開始から終了までに, 水平力と垂直力を同時に強めながら加えていること から, 鈿子の先端が奥へ進みすぎてしまら形で力を加えていることが推察された. 剥離作用力の定量化は, 剥 離技術の原理を理解する手段の一つとして有用であると考兄られた.

キーワード：腹腔鏡手術，技術評価，銈子作用力 


\section{1.はじめに}

近年，安全な手術の普及を目的とし，手術技能の分 析や伝達に関心が寄せられている。しかしながら手術 技能は定量化することが困難であるものが多いため, 技能分析を行らことは容易ではない，手術に持ける基 本操作の技能分析に関しては，手の甲にセンサを取り 付け，手の移動距離やタスク処理時間を調べる ICSAD (the Imperial College Surgical Assessment Device) ${ }^{1,2)}$ や, 手術針子の先端の軌跡を明らかにする TrEndo（Training in Endoscopy) ${ }^{3)}$ や HUESAD (Hiroshima University Endoscopic Surgical Assessment Device) $)^{4)}$ と呼ばれるシ ステムなどが開発されている，現在までに，熟練者と 初心者の技能が分析され，熟練者之初心者の技能差が 明らかにされているが，報告されている技能分析は， 鉗子の移動距離や両手の協調運動率，タスクの処理時 間などの手術操作の中の基本的な操作 ${ }^{5}$ や，縫合操作 に関するもの が多い，現在までに，鉗子先端に力を 加光蔵器から臓器を剥がす操作である剥離操作に和け る技術分析は行われていない。

今回我々は，操作中の鈿子先端に加わる力を計測す ることが可能なシステムを作成し，異なる技術レベル の医師に打忷る剥離技能の技術分析を目標とし，操作 中に術者が加える力の方向について検討を行った.

\section{2. 作用力計測システムの作成}

剥離操作を行ら場合，鉗子先端に打甜力は鉗子の
長軸方向である垂直力と鈿子長軸方向に対して垂直方 向である水平力の 2 方向に大きく分けられ，はじめに 垂直方向に力を加光た後に, 水平方向に力を加光剥離 を行う。熟練者と初心者の操作では，垂直力を加えた 後に水平力を加光るまでの時間や，剥離操作中に加兄 る力の垂直力と水平力の割合の推移が異なると予想さ れるため, 今回は垂直力，水平力の 2 万向の力を計測 することが可能なシステムを作成して作用力を計測し た.

全長約 $300 \mathrm{~mm}$ の先端へら型内視鏡用鉗子を先端か ら約 $6 \mathrm{~cm}$ の部位で切断し，両断端の間に，ひずみ式 3 軸力覚センサを装着することで，鉗子先端に作用する 力の計測が可能な鉗子を作成した．計測される力の方 向は，鉗子長軸方向である垂直力，鉗子長軸飞対し垂 直方向である水平力の 2 方向とした（Fig. 1）.

\section{3. システムを用いた作用力計測実験}

本研究では，上記システムを用い作用力計測実験を 行った。死体豚から摘出した腎動静脈付きの腎臓を各 術者に対し一つ用意した。標本の選択条件は，腎臓， 腎動脈，腹部大動脈の腎動脈起始部と同部位を含を腹 部大動脈の壁が含まれることとし，剥離操作中に腎臓 と腎動脈の位置が変化しないよう注射針を用いて，腎 動脈起始部付近の大動脈壁および，腎周囲の脂肪をゴ ム板に固定した，固定した臓器は，医師が鈤子操作を トレーニングするために日常的に使用する練習用具で あるボックストレーナー内に配置した（Fig. 2)。ボッ

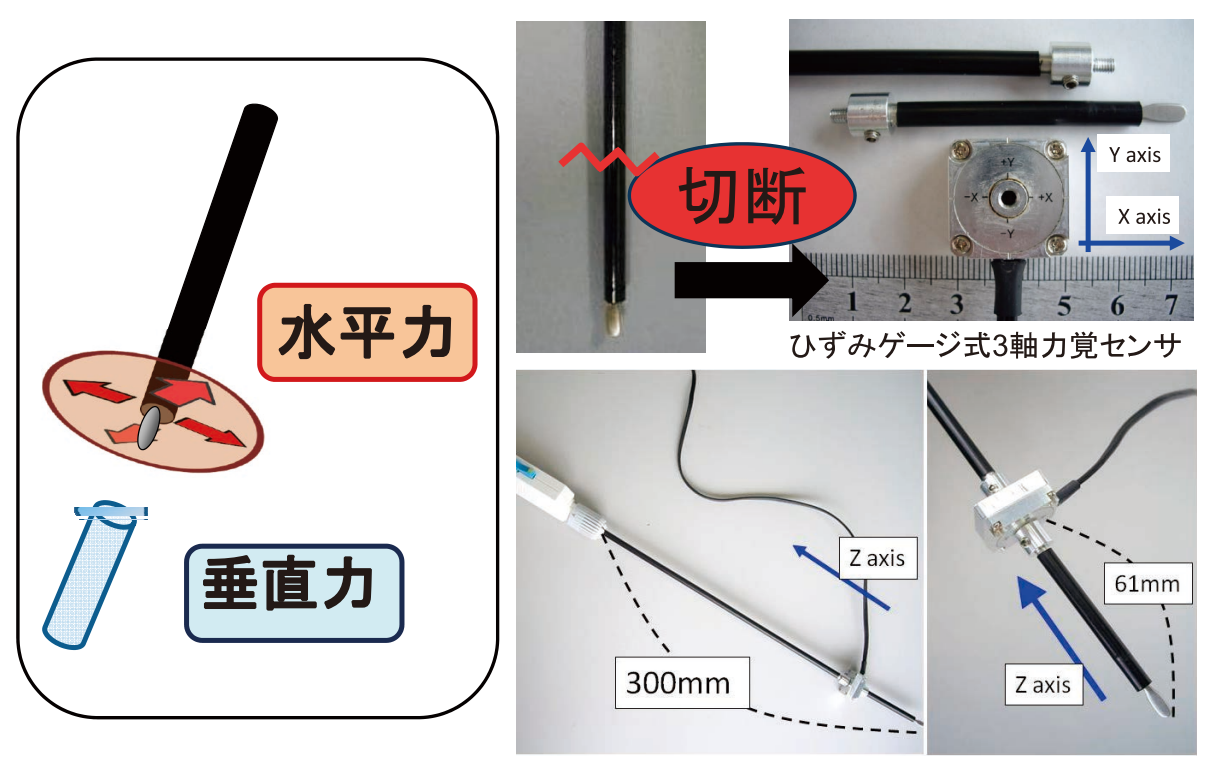

Fig. 1. 作成鉗子 


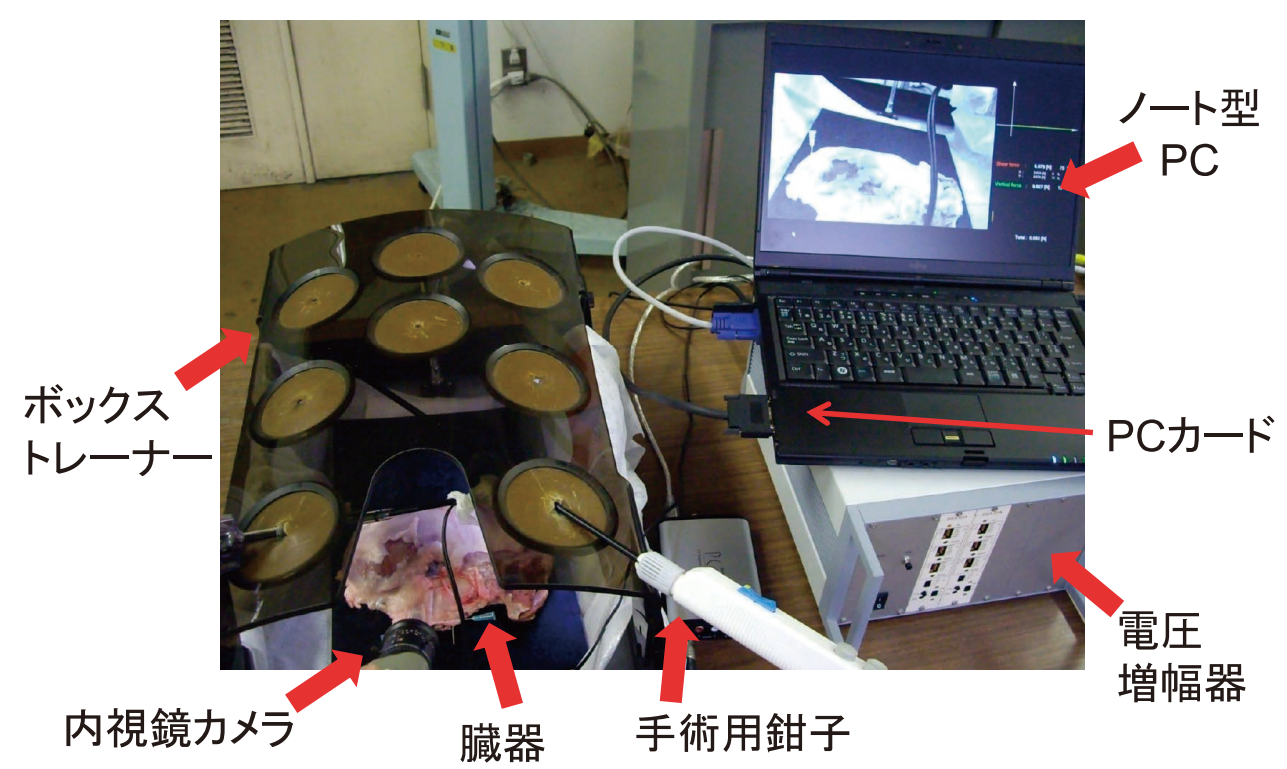

Fig. 2. システム全体像

クストレーナー内の様子は内視鏡カメラを通じてノー ト型パソコンのモニタに映しだされ，術者はモニタを 見ながら手術鉗子を用い剥離操作を行った。

計測対象は腎動脈から周囲脂肪組織を剥離する操作 であり，利き腕に扣ける鉗子先端作用力の計測を行 い, 力の方向の検討を行った. なお, 利き腕と対側に は，センサのない同型の鉗子を持ち操作を行った，臓 器に触れた時点を剥離操作の開始とし, 鉗子が蔵器か ら離れた時点を剥離操作終了とした。 また剥離開始か ら剥離終了までを 1 回の剥離操作とし, 実験では術者 に剥離操作を 10 回行らよう指示した. 剥離操作が連 続して行われていた場合や臓器から鉗子が外れ操作が 途中で終了した場合は，計測対象から除外した。

被験者は腹腔鏡手術熟練者 5 名（腹腔鏡手術執刀数, 80-750 例; 中央值 150 例), 初心者 5名 (2-5 例; 中央 值 3 例) とした. 鉗子先端が蔵器に触れてから離れる までの 1 回の剥離操作をワンストロークとし同操作を 10 回ずつ行った。評価項目は, ワンストロークに要 した時間（T)，垂直力及び水平力がそれぞれピーク を迎えるタイミング（ワンストロークの剥離時間を $100 \%$ とし垂直力，水平力がピークとなるまでの時間 を\%表示）とした。 また，全剥離操作に扣ける垂直 力・水平力の経時的推移の評価を行った.

\section{4. 結 果}

ワンストロークの剥離時間の平均値に関しては, 熟 練者が $2.6 \pm 0.6$ 秒で, 初心者の $3.1 \pm 0.8$ 秒より有意に
短い時間で剥離を行っている結果となった（MannWhitney U test: $\mathrm{p}=0.0009$ ）（Fig. 3）。むた，剥離作用力の

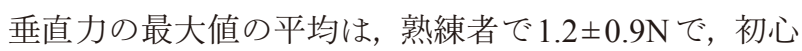
者で $1.5 \pm 0.5 \mathrm{~N}$ であり（Mann-Whitney U test: $\mathrm{p}=0.0026 ）$, 水平力の最大值の平均は, 熟練者で $2.6 \pm 1.5 \mathrm{~N}$, 初心

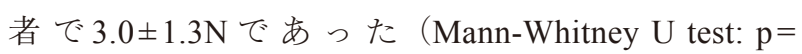
0.0193). ピークのタイミングに関しては，水平力は熟 練者 $(72.2 \pm 4.2 \%)$ と初心者 $(70.3 \pm 4.0 \%)$ では大きく 差は認めなかったが，垂直力は，熟練者（36.6 $55.6 \%)$ が初心者 $(65.0 \pm 10.5 \%)$ より有意に早くピークを迎える 結果となった（Mann-Whitney U test: $\mathrm{p}<0.0001)$ (Fig. 4).

さらに, 垂直力・水平力の経時的推移として, 横軸 をワンストロークの剥離時間とし, 縦軸を垂直力・水 平力の作用力の大きさとしてグラフ表示を行ったとこ ろ（Fig. 5), 熟練者は初心者に比べ, 垂直力が早いタ

[秒]
6
5
4
3
2

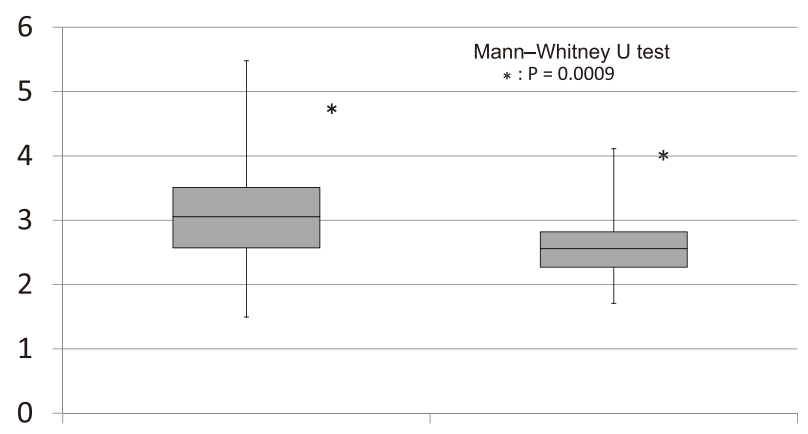

初心者

熟練者

Fig. 3. 剥離時間 


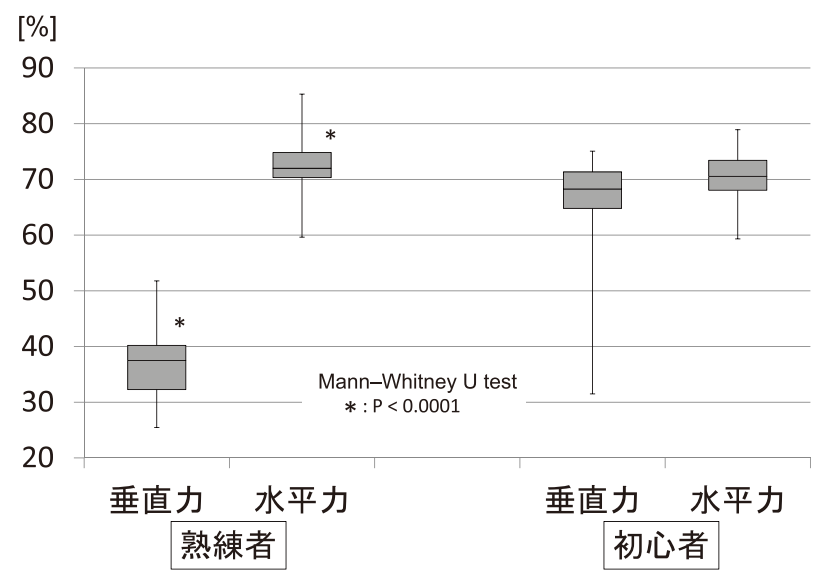

Fig. 4. 作用力のピークのタイミング

イミングでピークとなるよう作用力を加える傾向があ ると考えられた。

\section{5. まとめと今後の課題}

一般的に剥離を行う際, 他の臓器や血管が剥離部位 より奥に隠れて存在する可能性がある。そのため術者 は，鉗子先端を直視で確認できない部位へ進め過ぎな いよう注意を払ら必要がある。今回の結果では熟練者 は，剥離開始後に垂直力を加えた後に，緩める時間を 比較的短くしながら，水平力を加えていた。 このこと から，鉗子先端が剥離を行っている部位より奥へと進 み過ぎないように動かし，臓器損傷を避けるための安 全な操作を行っていると推察できた。一方で初心者 は, 剥離開始から終了までに, 垂直力と水平力を剥離
後半にピークを迎えるように加えているという結果と なった。このことから，鉗子が剥離部位より奥へと進 み，先端が確認できなくなるよう操作を行い，隠れた 臓器や血管を損傷する可能性があると考えられた。以 上の作用力測定結果から，初心者の剥離技術を熟練者 の剥離技術に近づけるには，垂直力と水平力のピーク の間隔をあけ，垂直力を加え緩める時間をできる限り 短時間とし，垂直力が緩み始めたころに，水平力を加 え始めその後にピークとするように指導する必要があ ると考えられる．鉗子の動きとしては，垂直方向の力 を加えた後, 水平方向に力を推移させる際に, 剥離を 行っている部位より鈿子が奥へ進みすぎないよう指導 することが必要であると考えられた。

本システムの利用により，異なる技術レベルの術者 が加えている作用力を理解することが可能であった が，本稿のデータは被験者数が少なく preliminaryな ものであるため, 我々は熟練者, 習熟者, 初心者, 各 10 名の作用力の違いに関して比較検討を行い，技術 レベルの向上とともに垂直力がピークを迎えるタイ ミングが，より速くなる傾向にあることを報告してい $ろ^{7)}$.

将来的には，本システムをトレーニングシステムや 指導ツールとして使用すれば，力の方向といら情報を もとに助言を行ら新しい指導方法が可能となり，手術 技術の習得の補助を行らことが期待できると考えられ る。また現在普及が進んでいる robotic surgeryにおい ても作用力計測アームの開発が進めば，本研究で用い た作用力のパラメータをもとに安全な作用力の検討が 行われると考光らる。

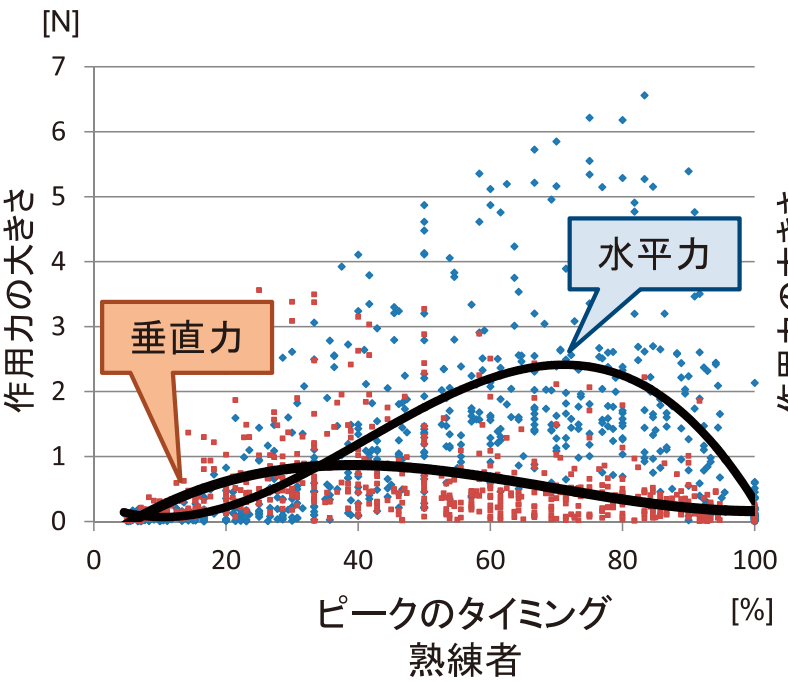

[N]

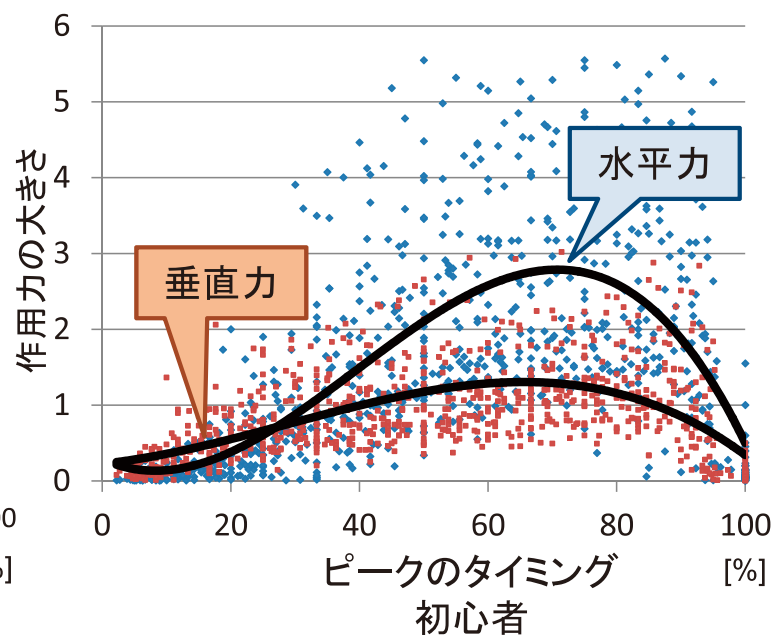

Fig. 5. 垂直力 - 水平力の推移 
本文は，学位論文を基に，第 13 回関西医科大学医 学会賞飞応募講演（2014年 2 月 14 日）し，優秀賞を 受賞した際の発表要旨でもある。

\section{文献}

1. Moorthy K, Munz Y, Sarker SK and Darzi A. Objective assessment of technical skills in suregery. Brit Med J 327: 1032-1037, 2003.

2. Datta V, Mackay S, Mandalia M and Darzi A. The use of electromagnetic motion tracking analysis to objectively measure open surgical skill in the laboratory-based model. J Am Coll Surg 193: 479-485, 2001.

3. Chmarra M, Jansen F, Grimbergen C and Dankelman J. Retracting and seeking Movements during laparoscopic goaloriented movements. Is the shortest path length optimal? Surg Endosc 22: 943-949, 2008.
4. Egi H, Okajima M, Yoshimitsu M, Ikeda S, Miyata Y, Masugami H, Kawahara T, Kurita Y, Kaneko M and Asahara T. Objective assessment of endoscopic surgical skills by analyzing direction-dependent dexterity using the Hiroshima university endoscopic surgical assessment device (HUESAD). Surg Today 38: 705-710, 2008.

5. Moorthy K, Munz Y, Dosis A, Bello F, Chang A and Darzi A. Bimodal assessment of laparoscopic suturing skills. Construct and concurrent validity. Surg Endosc 18: 1608-1612, 2004.

6. Nageotte F, Zanne P, Mathelin M and Doignon C. A circular needle path planning method for suturing in laparoscopic surgery. <http://eavr.u-strasbg.fr/ christophe/publications/ icraNZMD.pdf\#search='A circular needle path planning method for'> [accessed July 17, 2009].

7. Yoshida K, Kinoshita H, Kuroda Y, Oshiro O and Matsuda T. Analysis of laparoscopic dissection skill by instrument tip force measurement. Surg Endosc 27: 2193-200, 2013. 